\title{
AZ ÉLMÉNYMENEDZSMENT KONCEPCIONÁLIS ALAPJAI
}

Az élménymenedzsment vizsgálatát indokolja, hogy a fogyasztói élmény mindinkább az értékteremtés kulcstényezôjévé válik. Jelentôsége mára meghatározóvá vált. Erról tanúskodik az is, hogy az utóbbi másfél évtizedben több élménymenedzsment-koncepció is születettés többen a fogyasztást mint élményt vizsgálták. A cikk az élménymenedzsment koncepcionális alapjainak feltérképezésére törekszik a koncepciók közös pontjainak és ellentmondásos tételeinek elemzésén keresztül. A tanulmány többek között rámutat arra, hogy a koncepciók terén az egyik fö törésvonal az élményteremtés eltérố módjaiban rejlik, ugyanakkor több területen is egyetértenek, amely alapján következtethetünk egy közös nevezốre - az élményközpontú menedzsment szemléletére.

\section{Kulcsszavak: fogyasztói élmény, közös élményteremtés, elóállított élményteremtés, élménygazdaság.}

A tévében, az interneten, az utcán, a magazinokban mindenhol reklámokba botlunk, amelyek újabb, jobb, izgalmasabb, élvezetesebb, biztonságosabb, utánozhatatlan élményeket ígérố termékeket és szolgáltatásokat népszerúsítenek. Az éttermek, autógyártók, ingatlanfejlesztők, háztartási elektronikát gyártók stb., a vállalatok széles spektrumát képviselik, amelyek termékeik és szolgáltatásaik fogyasztása során egyedi élményt kínálnak. Hovatovább, az élmények már nemcsak a termék vagy a szolgáltatás hozzáadott értékeként értelmezhetők, hanem önmagukban értékes árucikként is. „A fogyasztók a megszerzett termékek és szolgáltatások elfogyasztásából származó élményre vágynak, nem pedig a tárgyak és szolgáltatások megszerzésére" (Puczkó, 2009: 25. old.).

A vevơi élménykoncepció a nyolcvanas években bukkant fel, és a 'mainstream' szakirodalomnak ellentmondva (amely a fogyasztóra mint racionális döntéshozóra tekintett) egy új, tapasztalati szemléletet hangoztatott. Holbrook és Hirschmann (1982) hangsúlyozta az emóciók szerepét a magatartásban, és annak a tényét, hogy a fogyasztók érző lények ugyanúgy, mint gondolkodók és cselekvő́k. Mindennek ellenére a vevői élménykoncepció csak a kilencvenes évek végén terjedt el, Pine és Gilmore Experience Economy (magyarul: Élménygazdaságtan) címú könyve megjelenésével. Pine és Gilmore úgy tekintett az élményre, mint egy új gazdasági ajánlatra, amely egy új, feltörekvő szintet jelent az árucikkek, termékek és szolgáltatások terén - mindezt pedig a gazdasági érték fejlődésének tartják. Innentól kezdve a vevôi élménykoncepció virágzó időszaka következett, több publikáció is megjelent, elsősorban menedzsmentfókuszú könyvek és cikkek a tanácsadók tollából, ugyanakkor pár kutató is hozzájárult a vevôi élmény szakirodalmához (pl. Addis - Holbrook, 2001; Caru - Cova, 2003; LaSalle Britton, 2003; Prahalad - Ramaswamy, 2004; Schmitt, 1999, 2003; Shaw - Ivens, 2005; Smith - Wheeler, 2002). A fogyasztás újraértelmezése szerint a fogyasztás egy holisztikus élmény, amelynek résztvevője az egyén (a vevővel ellentétben) és az egyén interakciója a vállalattal, illetve a vállalat ajánlatával (LaSalle Britton, 2003).

A cikk célja a vevơi élménykoncepció és az élménymenedzsment-szemléletek koncepcionális vizsgálata. Az élménykoncepció mint gazdasági szemlélet bemutatása után az élmény definiálása és a fogyasztás élményspektrumának jellemzésére kerül sor, amely megfelelő értelmezési keretet nyújt a különféle élménymenedzsment-koncepcióknak. Ezt követően a cikk rátér az egyes élménymenedzsment- és élménymarketing-tételek elemzésére, összegzésképp pedig a fóbb eltéréseket és egyezéseket vizsgálja és szintetizálja. 


\section{Az élménygazdaság}

Az élménygazdaság primer és szekunder dimenziókra osztható (Sundbo, 2009). A primer dimenzióba sorolhatók azok a vállalatok, amelyek termelési folyamatának középpontjában az élmények állnak. Ilyenek például a fesztiválok, a filmes szakma, a sportklubok, a számítógépes játékokat gyártó cégek, a dizájntervezô cégek és nem utolsósorban a turisztikai vállalatok. A fennmaradó vállalatok sora mind a szekunder dimenzióba tartozik. Azonban Pine és Gilmore (1999) szerint bármelyik szektorba tartozó vállalat képes az élményteremtésre a termék vagy a szolgáltatás kiegészítő elemeként. Meglátásuk alapján a fejlett világ a szolgáltatásalapú gazdaság irányából az élményalapú gazdaság felé halad. E megállapításukat az Egyesült Államok gazdasági növekedési mutatóinak elemzésére alapozták, ugyanis az adatokból kitűnt, hogy a szabadidős tevékenységek és a turisztikai vonzerốk - például a tematikus parkok, a mozik, a koncertek, a sportesemények - iránt nô a kereslet, és ez a szektor az ár, a foglalkoztatás és a nominális GDP szempontjából is felülmúlja az egyéb szektorokat. Ezt azzal magyarázták, hogy a szektor vállalatai olyan élményeket kínálnak, amelyek egyedi, emlékezetes és bevonódást lehetôvé tévő jellegük miatt magasabb szintû fogyasztói értékelésnek örvendenek. Más szolgáltatások ezzel szemben fokozatosan eltömegárusodnak, mivel a fogyasztók homogénnek vélik ezeket, ezért elsősorban az ár és az elérhetőség befolyásolja óket a vásárlásban.

Ehhez a tömegárusodási trendhez, amely több szektorban is megfigyelhető, az internet elterjedése jelentősen hozzájárult. E trendre turisztikai szempontból bizonyítékul szolgál például a fapados, diszkont légitársaságok piaci térnyerése, a szállodai rezervációs oldalak és az új on-line utazásközvetítők egyre meghatározóbb szerepe (Buhalis, 2003), valamint a yield menedzsmentrendszerek elterjedése. Ezek a piaci változások arra bátorítják a turistákat, hogy kedvezményes ajánlatok után kutassanak, és a legolcsóbb vagy a legkedvezóbb ár-érték arányú ajánlatot vásárolják meg. A fejlett fogyasztóvédelmi szabályok és a szolgáltatásmenedzsment növekvő standardjai ugyanis a minőség és a megbízhatóság garantáltnak vételéhez vezetnek fogyasztói oldalon.

Érdekesség, hogy Alvin Toffler (1970) jövókutató már harminc évvel Pine és Gilmore elôtt felhívta a figyelmet arra a paradigmaváltásra, ami a jövőben jelentősen befolyásolni fogja a termékeket és szolgáltatásokat, és egy következő hullámként jellemzik majd a gazdaságot. Ezt Toffler nevezte el élménygazdaságnak.

Az élményeket úgy definiálhatjuk, mint különböző gazdasági ajánlatokat, amelyek annyira különböznek a szolgáltatásoktól, mint a szolgáltatások a termékektől
(Pine - Gilmore, 1999). Ebben a szemléletben a sikeres élmények azok, amelyeket a fogyasztó egyedinek, emlékezetesnek és fenntarthatónak talál, szeretné megismételni ôket, és lelkesen terjeszti a hírüket.

\section{Az élmény koncepcionalizálása}

Az élmény egy összetett fogalom, melynek értelmezése sokféle módon lehetséges, és több tudományterületen pl. pszichológia, szociológia, üzleti tudományok - is meghatározó fogalomnak számít. Ennek köszönhetôen szakirodalmi megjelenése is nagyon gazdag és sokrétû. Az irodalomkutatás eredményei alapján az élményt többféle szempontból vizsgálhatjuk:

- a pszichológiai megközelítésú szemlélet az egyéni érzések, emlékezetesség, tudatosság és viselkedés fogalmak köré építi élménydefinícióit,

- a vállalati interpretációban a fogyasztó, a marketing, az érték és az értékteremtés fogalmak állnak a középpontban,

- a társadalmi megközelítésú szemlélet olyan fogalmakat vesz alapul, mint az életstílus vagy a társadalmi kontextus.

Az alább bemutatott definíciók jól szemléltetik ezt a változatosságot.

\section{Pszichológiai szemléletü élménydefiníciók}

A legáltalánosabb szinten az élmény ,,a cselekvés és befolyásoltság folytonos folyamata, amely jelentéssel bír az egyén számára" (Boswijk et al., 2007: p. 2.). Holbrook és Hirschman (1982: p. 132.) szerint az élmények azt az emocionális állapotot tükrözik, amelyek öszszetevői ,,a fantázia, az érzések és a jókedv állandó áramlása." Ez a definíció összhangban van Csíkszentmihályi (1975), Holyfield (1999) és Gobe, Gob és Zyman (2001) megállapításaival is. Carlson (1997) szerint az élmény a tudatos állapot momentumaiban felbukkanó gondolatok és érzések állandó áramlata.

\section{Vállalati szemléletú élménydefiníciók}

Hirschman és Holbrook (1982) szerint az élmény a fogyasztói magatartás azon tényezóje, amelyek multiszenzoriális, képzeleti és emocionális aspektusai az egyén termékkel való tapasztalatának. Egy másik definíció kiegészíti ezt, miszerint az élmény több tényezó egyvelege, amelynek köszönhetően a fogyasztó bevonódik az élménybe emocionális, fizikai, intellektuális és/vagy spirituális módon (Mossberg, 2007). Lewis és Chambers (2000) szerint az élmény nem más, mint a megvásárolt termékek, szolgáltatások és a környezet kombinációjának következménye fogyasztói oldalon. LaSalle és Britton (2003) egy alternatív definíciót fo- 
galmaz meg, amely kimondja, hogy az értékes élmény olyan termék vagy szolgáltatás, amely ha kombinálva van az ôt körülvevő élményekkel, az események önmaguktól értéket teremtenek, illetve fokozzák azt a fogyasztó számára. Ez az ideális - olyan átfogó érték szolgáltatása, amelynek köszönhetően a termék felülmúlja az átlagost, tehát rendkívülinek, akár megfizethetetlennek tû́nik. Más definíciók az élményhez intenzitást is kapcsolnak. A meghatározás, mely szerint fogyasztói szempontból az élmények élvezetes, megnyeró, emlékezetes találkozások azok számára, akik fogyasztják ezeket (Oh et al., 2007), összecseng Pine és Gilmore (1999) élménygazdaság-tételével.

\section{Társadalmi szemléletü élménydefiníciók}

Schmitt (1999: p. 25.) úgy határozza meg az élményt, mint ,a találkozás és helyzetek átélésének eredményét... az érzékekben, szívben és elmében kiváltott ingereket..., amelyek összekötik a vállalatot és a márkát a fogyasztó életstílusával, valamint az egyéni fogyasztó tevékenységeit és a vásárlási alkalmakat szélesebb társadalmi kontextusba helyezik."

Gentile et al. (2007) szerint a vevôi élmény a vevô és a termék, a vállalat vagy a szervezeti egység interakciójának sorozatából származik, amely reakciót idéz elô. Az élmény szigorúan személyes, és magába foglalja a vevő bevonódását különbözố szinteken (racionális, emocionális, szenzoriális-fizikai és spirituális).

Végezetül megállapíthatjuk, hogy összességében nincs olyan elmélet, amely komplex módon definiálná a turisztikai élmény jelentését és terjedelmét, noha több szerző is megpróbálkozott modellek megfogalmazásával.

\section{A fogyasztás élményspektruma}

Caru és Cova (2007) megalkotja a fogyasztási élmények kontinuuma modellt (1. ábra), melynek egyik végén azok az élmények állnak, amelyeket a fogyasztó alkotott, a másik végén azok, amelyeket nagyrészt a vállalatok hoznak létre (előállított élmények). A két véglet között pedig a közös élményteremtés koncepciója áll, amikor is a fogyasztó és a vállalat is részt vesz az élményteremtésben. A szolgáltató szerepe és marketingszemlélete is különbözik e három különbözố típusú élményfogyasztás esetében. Az (1) egyéni élményteremtés esetében a vállalat a tradicionális, termék- vagy szolgáltatás-központú marketingstratégiát alkalmazza, (2) az elóállított, avagy színre vitt élményteremtés, amikor az élmény a vállalat által megtervezett és rész- letekbe menóen meghatározásra került - a fogyasztó ez esetben részese az élményeknek, míg (3) a közös élményteremtés, amikor a vállalat egy optimális élménykörnyezet kialakítására törekszik, amelyben a fogyasztó megalkothatja saját élményeit.

1. ábra

A fogyasztási élmény kontinuuma 
Az élménygazdaságtan-szemlélet hangsúlyozza, hogy az előállított élmények a hozzáadott érték forrásai (Pine - Gilmore, 1998, 1999; Gilmore - Pine, 2002a, 2002b; Boswijk et al., 2007). A fogyasztó magasabb fokú elégedettséget tapasztal, míg a vállalat számára az értéknövekedés a megnövekedett profitból származik, amit a magasabb árak és/vagy a megnôtt kereslet biztosítanak.

Pine és Gilmore (1999) Goffman drámaszemléletét alkalmazza az élménygazdaság üzleti folyamatainak, illetve az élmény-elóállítás folyamatának koncepcionalizálására. Úgy vélik, hogy az előadás-elméleten (drámán) alapuló üzleti stratégiának kell felváltania az üzleti gyakorlatban oly gyakran alkalmazott katonai stratégiát, és a drámának kell az üzlet központi metaforájává válnia.

Az élménygazdaság, azaz az előállított élmény koncepciója színházi terminológiát adaptál, így lettek az ügyfélszolgálat munkatársaiból színészek, a vevôkból közönség, a fizikai környezetból díszlet, és elóadás lett az élmény szolgáltatói megjelenítésébool. Ez a típusú alkalmazás nem újdonság, hiszen a szolgáltatásmenedzsment szakirodalmában már egy évtizeddel azelótt is megjelent (Grove - Fisk, 1989; Grove et al., 1992) és a fogyasztói élmény leírására is alkalmazták (Holbrook - Hirschman, 1982). De Pine és Gilmore (1999) ennél továbbmegy, és a munka is színház metaforával áll elő az előállított élmények köré épülő gazdasági szektorok és vállalatok leírására. Az előállított élményteremtéskoncepció együttesen hangsúlyozza az alábbi tényezôk fontosságát a menedzsment számára:

- a szolgáltatáskörnyezet, illetve élménykörnyezet kialakításának, dizájnjának és a légkörének fontossága (Bitner, 1992; Pine - Gilmore, 1999; Schmitt, 1999),

- az alkalmazottak és vevók közötti interakció fontossága (Berry et al., 1985; Gronroos, 1985; Grove et al., 1992; Pine - Gilmore, 1999),

- az alkalmazottaknál fontos az egyéni személyiségelemek beépítése a szerepükbe (Pine -Gilmore, 1999),

- forgatókönyvek írása minden egyes szolgáltatási helyzetre, azaz minden egyes színpadra vonatkozóan, a dráma és mesemondás metaforáinak alkalmazásával (Grove et al., 1992; Pine - Gilmore, 1999; Schmitt, 2003; Shaw - Ivens, 2005),
- a szolgáltatásnyújtás integrált termelés a szó filmszerú (folytonosságmenedzsment), mintsem üzemszerú értelmében (például: ahányszor a vevő kapcsolatba lép a vállalati márkával, mindig ugyanazt a magas minőséget kell észlelnie) (Pine - Gilmore, 1999; Schmitt, 1999, 2003; Shaw Ivens, 2005; Smith - Wheeler, 2002),

- meglepetésfaktor beépítése az élménybe/termékbe/szolgáltatásba (Pine - Gilmore, 1999; Hetzel, 2002),

- rendkívüli élmény ígérete és teljesítése (Hetzel, 2002; LaSalle - Britton, 2003),

- az érzékek stimulálása (Schmitt, 1999; Pine Gilmore, 1999; Hetzel, 2002; Hultén et al., 2009).

Az előállított élménymenedzsmentre stratégiai és egyben taktikai eszközként is tekinthetünk. A szemlélet szerint annak az értéknek a megértése, amelyet az élmény a vevoók számára jelent, kulcsfontosságú, és a vállalati márka része kell, hogy legyen a versenyképes stratégia szempontjából. A koncepció terén a dráma fogalma a vállalat és a vevô közötti interakciót jelöli. Az, hogy mennyire tudja az élmény az egyént lekötni, menynyire lesz számára az élmény meghatározó, attól függ, hogy milyen mértékú interakció jön/jöhet létre az egyén és a termék között. Ezért a vállalat érdeke a fogyasztó minél mélyebb bevonása az élménybe. Továbbá, ugyanúgy, mint a drámában, az interakció eredménye az egyéni fejlődés. Tehát azok a szolgáltatók által kínált élmények képesek létrehozni a legnagyobb értéket, amelyek valamilyen szintú egyéni átalakulást tesznek lehetővé.

2. ábra

\section{Az élmény négydimenziós modellje}

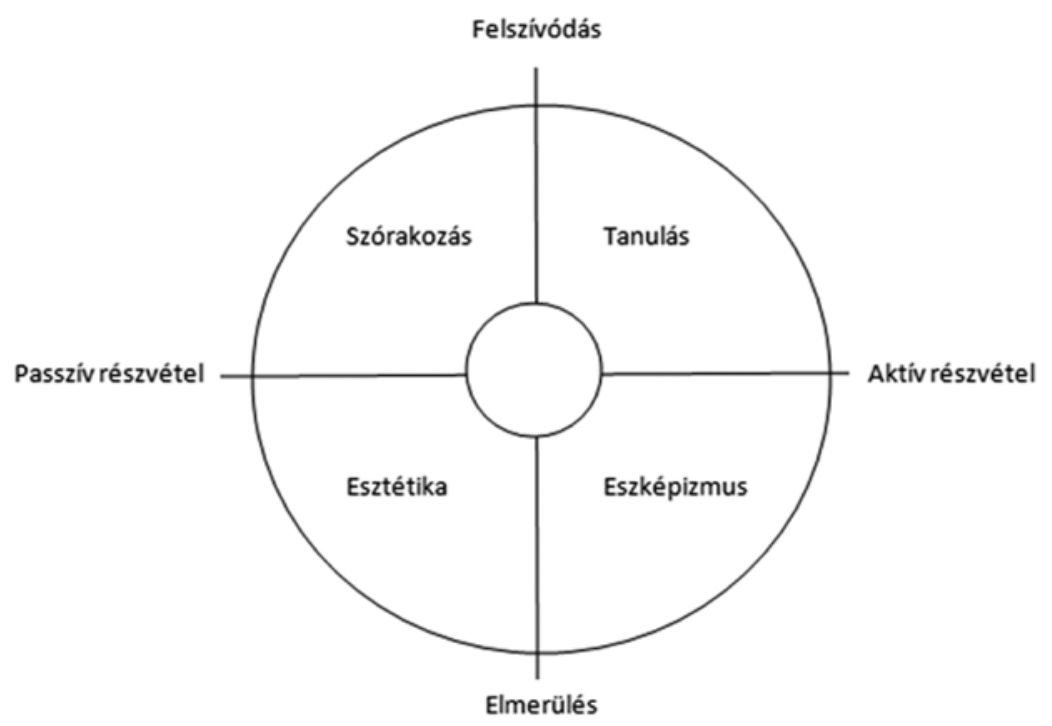

Forrás: Saját szerkesztés Pine és Gilmore (1999: p. 30.) alapján 
Pine és Gilmore (1999) az élmények négy dimenzióját különböztette meg (2. ábra), amelyek egymástól a fogyasztói bevonódás és részvétel szintjeiben térnek el. A négy dimenzió a (1) a szórakozás, (2) a tanulás, (3) az esztétika és (4) az eszképizmus. A szórakozás- és esztétikadimenziókat a passzív részvétel jellemzi, míg a tanulás- és eszképizmusdimenziókat az aktív részvétel, mivel a fogyasztó kulcsfontosságú szerepet játszik a folyamatban. A felszívódás-elmerülés tengely menti értelmezésben a turista tipikusan felszívja a szórakoztatás- és tanulásdimenzióba tartozó élményeket, valamint elmerül az esztétika- és eszképizmusdimenzió élményeiben. A felszívódás fogalmát a szerzőpáros úgy definiálja, mint "az egyén figyelmének lekötését és az élmény elmébe való felszívását", elmerülés alatt pedig azt értjük, amikor az egyén „fizikai (vagy virtuális) módon az élmény részévé válik" (Pine - Gilmore, 1999: p. 31.). A szerzốk szerint a négy élménydimenzió együttes kombinációja eredményezi az optimális fogyasztói élményt.

A szórakoztatás dimenziójába tartozó élmények, mint például színházi előadás, általában passzív részvételt jelentenek a fogyasztó számára. Ezt a dimenziót a különbözô szektorokban holisztikus módon érdemes alkalmazni, és szórakoztató elemeket bevonni a szolgáltatásnyújtásba. A tanulásdimenzió élményeinek átélése során a fogyasztók új készségeket sajátítanak el, vagy fejlesztik a már meglévốket. Az eszképizmusdimenzió élményei azok, amelyek mind aktív részvételt, mind elmerülést jelentenek a fogyasztó számára. Az esztétikadimenzió élményeinek átélôi passzívak az élmény pillanatában, például ha épp a Meteorák természeti csodáját szemlélik görögországi utazásuk során, vagy a tengerparti naplementében gyönyörködnek. Petkus (2004) szerint a szórakoztatás dimenziója az érzékelésen keresztül tudatosul, a tanulási dimenzió a tanuláson, az eszképizmus dimenziója a cselekvésen, az esztétika dimenziója pedig a jelenléten.

A modell empirikus tesztelése viszont nem igazolta a modellt teljes mértékben (Oh et al., 2007; Hosany - Witham, 2009; Mehmetoglu - Engen, 2011), amely arra enged következtetni, hogy az élmény kimeneteléhez nem kell feltétlenül mind a négy élménydimenziónak hozzájárulnia.

Schmitt (1999) véleménye is egyezik abban, hogy a marketing feladata a megfelelő élménykörnyezet kialakítása a kívánt rendkívüli vevối élmény elôidézésére. Szerinte az élmény minősége nem e tevékenység típusának dimenzióitól, hanem az észlelés módjától, illetve annak intenzitásától és összetettségétől függ. Modelljében öt stratégiai szintú élményelemet határoz meg:

- szenzoriális tapasztalás (érzékelés),

- affektív tapasztalás (érzés),

- kreatív kognitív tapasztalás (gondolkodás),
- fizikai tapasztalás, magatartás és életstílus (cselekvés) és

- társadalmi identitásbeli tapasztalás, amely egy bizonyos referenciacsoporthoz, kultúrához való kapcsolódásból fakad (kapcsolódás).

Gentile et al. (2007) Schmitt modelljét korrigálva a vevối élmény hat dimenzióját különbözteti meg: (1) szenzoriális (érzékszervi) dimenzió, (2) emocionális dimenzió, (3) kognitív dimenzió, (4) pragmatikus dimenzió, (5) életstílusbeli dimenzió és (6) kapcsolati dimenzió.

Az előállított élményteremtés koncepcióját alkalmazók arra törekednek, hogy emlékezetes és személyre szabott élményeket biztosítsanak (Arnould et al., 2002). Az élmények kínálata és beépítése a termékbe vagy szolgáltatásba annak megkülönböztetésére és eltömegárusodásának megakadályozására szolgál, miközben minden szektorban alkalmazható, így például a kereskedelemben is, ahol ebból adódóan olyan fogalmak jelentek meg, mint a retailtainment, a kiskereskedelem és a szórakozás szavak egybeolvasztásával, vagy a shoptainment, a bolt és a szórakoztatás szavak összeforrasztásával, amelyek a fogyasztók fizikai és emocionális bevonását is megcélozzák (Kim, 2001).

\section{A közös élményteremtés}

Széles körben elfogadott nézet, hogy az egyén számára a közös élményteremtés az, ami értéket teremt. Amikor a 2000-es évek elején Prahalad és Ramaswamy (2000, 2003, 2004a, 2004b) elkezdték tanulmányai sorozatának írását, azt ecsetelték, hogy a gazdasági értékteremtés helye mindinkább változik, és az érték nem a vállalaton belül, hanem a fogyasztó és a vállalat közötti interakció során jön létre. A közös értékteremtés szemlélete úgy tekint a fogyasztóra, mint a használati érték teremtôjére és az értékteremtésben részt vevő egyik félre. A fogyasztó tudása és szakértelme alapján tudatosítja saját potenciáját és erőforrásait a fogyasztás során, és egyrészt megkülönböztetésre törekszik, másrészt saját identitásának kialakítására, fenntartására vagy fejlesztésére (Firat - Venkatesh, 1995). Ugyanakkor a társadalmi hálók létrehozása és a hozzájuk való csatlakozás is cél lehet (Holt, 1995).

A közös élményteremtés koncepciója alapján a vállalat nem árulja és nem elóállítja az élményeket, hanem olyan kontextust, illetve élménykörnyezetet alakít ki, amely elôsegíti az élményeket, amelyekbe a fogyasztók saját egyedi élményeik kialakítása érdekében részt vesznek, miközben közös értékteremtő folyamat valósul meg. Prahalad és Ramaswamy (2004a) koncepciójában a termékek és szolgáltatások az élménykörnyezet részei, ahol a közös élményteremtés zajlik. Ugyanak- 
kor a termékek és szolgáltatások legfontosabb szerepe az egyén és közösségek által létrehozott élmények közvetítésében van.

Az interakciónak is meghatározó szerepe van az élményteremtésben. Mivel a fogyasztók sokasága mind más és más interakciót igényel, az értékteremtő folyamatnak a közös élményteremtés számtalan variációját kell lehetővé tennie. Ezért a közös élményteremtés minősége a vállalat és a fogyasztó közötti interakciók infrastruktúráján múlik, pontosabban, hogy milyen széles spektrumon, hány különbözó élmény kialakítására kerül sor. A közös értékteremtés építóelemei a párbeszéd, hozzáférés, átláthatóság és kockázatmegosztás (Prahalad - Ramaswamy, 2004a). Ahhoz, hogy a vállalat versenyképes maradjon, hatékonyan kell újítania élménykörnyezetét, amely lehetôvé teszi a közös élményteremtés változatosságát.

A közös értékteremtés nem egy új keletû dolog, és nem is a XXI. század specifikus jelensége. Ritzer és Jurgenson (2010) szerint a termelés és a fogyasztás egy ugyanazon érme két oldala, a közös értékteremtés mind a kapitalista, mind a nem kapitalista gazdaságok meghatározó jelensége. A szerzók hangsúlyozzák, hogy a jelen társadalmi átalakulások, mint például az internet elterjedése, de fóképp a felhasználók által generált tartalom, ismertebb nevén Web 2.0, befolyásolta azt, hogy a közös élményteremtés gyakorlata a vállalatgazdasági értékteremtés középpontjába kerüljön.

Ugyanakkor az információs technológiák fejlődése még inkább erôsítette a fokozódó fogyasztói aktivitás trendjét is. Prahalad és Ramaswamy (2004b) szerint minél több releváns információ jut el az egyénhez, annál tapasztaltabb, és ezáltal személyre szabottabb döntéseket képes meghozni, illetve nagyobb beleszólást igényel a termék vagy szolgáltatás megvásárlásába, és aktívabban veszi ki részét a fogyasztásban is. Összességében megállapítható, hogy a fogyasztók aktívabban szeretnének részt venni a fogyasztásban, és a termék, illetve a szolgáltatás megtervezésében is.

Az egyik legfontosabb tényező vitathatatlanul az internet elterjedése és a technológia gyors ütemú fejlôdése. A kommunikációs technológiák terén zajló forradalom lehetôvé teszi az ötletek és az információ áramlását, és decentralizálják azt a vállalatoktól (Fisher - Smith, 2011). A tartalmat és a márkát többé már nem a vállalatok írják, hanem a fogyasztók és közösségeik. A fogyasztók iróvá váltak, az új technológiák pedig kétirányúsították a vállalat és a fogyasztó közti kommunikációt, ezzel nagyobb interaktivitást biztosítva (Fisher - Smith, 2011). Ennek a folyamatnak köszönhetốen a fogyasztók egyre nagyobb kontrollhoz jutnak az ajánlatok megalkotásában (Lusch et al., 2006). A fo- gyasztói tartalom már szinte ugyanakkora befolyásoló erôvel bír, mint a fizetett reklám.

A köztudat szerint a fogyasztói közösségek egy-egy szeretett termék vagy márka köré épülnek. Ugyanakkor az új domináns marketingparadigma (Vargo - Lusch, 2004) felhívja a figyelmet, hogy a termék önmagában nem egy véget jelent, inkább kapcsolatot, élmények és ötletek megosztását a fogyasztók között. Tehát a terméknek másodlagos szerepe is lehet, míg a hangsúly a közösségi tagok interakciójára és tapasztalatainak megosztására kerül.

A közösségek kialakítása azonban nemcsak a fogyasztók privilégiuma, és a vállalatok hálózatba tömörülése is szükséges a versenyképes fogyasztóiélményajánlatok létrehozására (Fischer-Smith, 2011; Prahalad - Ramaswamy, 2004). A neo-törzsek, avagy új közösségi érdekcsoportok egyre inkább az információszerzés, tudás, szórakozás és biztonság forrásává válnak az egyén számára (ETC, 2006).

Fischer és Smith (2011) szerint egyre több vállalat próbál az autentikus fogyasztást lehetôvé tévő ajánlatok létrehozásával a fogyasztók kedvében járni. A mai fogyasztó kontextusba illó, autentikus élmények iránt érdeklődik, valamint az élményszolgáltató és saját maga által meghatározott tevékenységek közötti egyensúlyra törekszik, amely szabad teret hagy a rögtönzésnek, a szabadságérzetnek és az önkifejezésnek (Binkhorst - Dekker, 2009). A közös értékteremtés koncepciója (Prahalad - Ramaswamy, 2004a) egy olyan szemlélet, amely a vállalatok részére lehetôvé teszi a fogyasztó mint társelőállító bevonását és az ajánlat személyre szabását. Ez a turizmus területén szembetúnően megmutatkozik, egyre több fogyasztó inkább saját maga által létrehozott élményeket keres, mintsem a szolgáltató által elő́llított élményeket - azáltal, hogy például a kreatív turizmus formáját vagy az önkéntes turizmust választják, jelentőségteljesebb élményben lehet részük (ETC, 2006).

\section{Az élménykoncepciók kritikája és szintézise}

Pine és Gilmore (1999) elméletét a Disneyland és más tematikus parkok sikerével illusztrálta. Ugyanakkor épp az élménygazdaságtan elméletében domináló, Disney-szerú eseteknek köszönhetően több kutató elutasítóan tekint az elméletre felületessége, múszerúsége és vállalat- és termékközpontúsága miatt.

Nijs (2003) kritikájában az élménygazdaságtan szemléletét túlságosan szenzációfókuszáltnak véli, amit az Egyesült Államok maszkulin kultúrájával magyaráz. Véleménye szerint a hangsúlyosabban feminin európai kultúrák esetében a vállalatoknak társadalmi és környezeti értékeikre kell alapozniuk az élményteremtést a hoz- 
záadott (emocionális) fogyasztói érték elérése céljából. Ô az imagineering kifejezést helytállóbbnak véli annak a stratégiának a leírására, amikor a szolgáltató a vállalati folyamatokat a potenciális fogyasztói közösséggel megosztott értékeire építi. Caru és Cova (2007) is a rendkívüli élmények vízióját az észak-amerikai gondolkodásmód sajátosságának véli, amely a romanticizmusban gyökerezik. Szerintük az élményszemléletet nem szabad eltorzítani kizárólagosan a rendkívüli élményekre való koncentrálással, amely túlzottan reduktív és normatív módon értelmezi az élményszemléletet.

Ritzer és Liska (1997) megkülönbözteti az autentikus helyeket a szimulált környezetektől, és nem autentikusnak nevezi az élménymenedzsment magját alkotó elóállított élményteremtést. Holbrook (2001: p. 139.) elutasítóan tekint az élménymarketing elméleteire (mint pl. Pine - Gilmore, 1999; Schmitt, 2003), és úgy jellemzi, mint „,felettébb optimista, pozitív és opportunista kép a fogyasztói kultúráról, tele millenáris optimizmussal."

Prahalad és Ramaswamy (2004: p. 89.) a stratégiai gondolkodás fontosságát hangsúlyozza, amely túlmutat a Disney-világra alapozó élményközpontú marketingen, mert az vállalatközpontú, és a vevôt „emberi kellékként kezeli a gondosan előállított elôadásban.”

Morgan (2010) ilyen fajta kritikát túlzottnak tart, hiszen szerinte az előállított élmény koncepciója hívta fel az élmény jelentőségére a figyelmet. Binkhorst és Dekker (2009) szerint ezek a kritikák figyelmeztetnek az elóállított élménygenerálás gyenge pontjaira, amely olyan jelzókkel írható le, mint: kommersz, mesterséges, felszínes, és ezért nem mindig alkalmas a mai fogyasztók meggyőzésére.

Cova és Caru (2009) azonban részletesen elemzi az élmény marketingkoncepciójának szociopszichológiai háttérérét, és arra próbálják felhívni a figyelmet, hogy a kínálati oldal túlzott fókusza a rendkívüli és emlékezetes élmények menedzsmentjére, nincs jó hatással a társadalom lélektanára és a fogyasztói magatartásra. Javaslatuk szerint, az élménymarketingnek a rendkívüli élmények helyett a hétköznapi élményekre kellene fókuszálnia.

Lugosi (2007) felhívja a figyelmet, hogy néhány emlékezetes élmény spontán jön létre. Ezért fel kell tenni a kérdést, szükséges-e egyáltalán az emlékezetes élmények menedzselése, hiszen az élmény elveszítheti autentikusságát, és egy Disney-szerú, mesterséges élménnyé torzulhat. Ugyanakkor ezt inkább veszélyfaktorként, mintsem törvényszerúségként értelmezi. Gillespie (2001) például rávilágít arra, hogy az ízlésalapú élmény esetében az élménymenedzsment eszközével hogyan hozható létre emlékezetes élmény, miközben az nem veszít autentikusságából.
Gibbs és Ritchie (2010) szerint a vevők különböző élményeket és különböző szintú szolgáltatói támogatást és interakciót igényelnek az egyes szituációkban.

$\mathrm{Az}$ élménymenedzsmentnek el kell mozdulnia az előállított előadások szolgáltatására való fókuszálásból abba az irányba, ahol a szolgáltató megteremti a megfelelő körülményeket és támogatást ahhoz, hogy a fogyasztó saját maga építhesse fel az élményét (Lugosi, 2008; Morgan et al., 2009; Prahalad - Ramaswamy, 2004). Gentile et al. (2007) szerint a legjobb élmények a vállalat és fogyasztó által közösen teremtett élmények.

Az elóállított élményteremtés és a közös élményteremtés koncepcióit összevetve, az élménykoncepciók szintézisét megkísérelve, a számos ellentmondásos pont mellett a hasonlóságokra is fény derül, amelyek az élménymenedzsment és az élménymarketing jellemzői:

- a fogyasztói élményeknek egyre meghatározóbb szerepe van az értékteremtésben,

- az élményközpontú szemléletek a fogyasztó aktív részvételét feltételezik, a szolgáltató érdeke az egyén minél mélyebb bevonása az élménybe,

- a fogyasztóval való interakciónak fontos szerepe van,

- az élményközpontúság vállalaton belül egy tudásban intenzív folyamatot eredményez,

- élményközpontú stratégiájukban a megfoghatatlan, eszmei erôforrások kiaknázására és hasznosítására építenek, mintsem materiális erőforrásokra,

- a vevốk várható érdeklődési pontjai és a vevốk által előre feltételezett élmények felmérésre kerülnek, a termelési fázisban (élménytémák kialakítása, adott módszerek és technikák alkalmazása) hasznosítják a vevoók várható érdeklődési pontjairól és élményeiról megszerzett tudást,

- az innováció középpontjában az új élménytémák kialakítása áll,

- a termékstratégiában az élményekben és nem a termékekben való gondolkodás a jellemzó, az élmény nem kontextus vagy termékkiegészító, hanem tartalom, amit alakítani és fejleszteni lehet,

- annak az értéknek a megértése, amelyet az élmény a vevő számára jelent, kulcsfontosságú, és a vállalati márka része kell, hogy legyen a versenyképes vállalati stratégia szempontjából.

\section{Összegzés}

A vevới élménykoncepció szakirodalmi áttekintésébôl megállapítható, hogy meglehetôsen sokszínú, és ebból kifolyólag a vevoói élmény interpretációja és koncepcionalizációja is szerteágazó. A különbségek 
ellenére a megközelítések egyhangúak abban, hogy a vevôi élmény ideiglenes és személyes jellegú azáltal, hogy a fogyasztó racionális, emocionális, érzékszervi, fizikai és spirituális módon vesz részt a fogyasztásban.

Az élménymenedzsment és -marketing a fogyasztói élmények középpontba helyezésének szemlélete. Az élménykoncepciók két típusa különböztethetô meg:

- amely az intenzív, rendkívüli, emlékezetes élmények létrehozására fókuszál és

- amely a közös élményteremtés megvalósulásának fontosságát hangsúlyozza a fogyasztás és az értékteremtés során.

Az élménymenedzsment-szemlélet nem egységes, mivel a menedzsment irodalommal foglalkozó szerzók különféle recepteket kínálnak az üzleti megújulás és siker kulcsaként (például Pine - Gilmore, 1999; Schmitt, 1999, 2003; Shaw - Ivens, 2005). Ennek ellenére az üzleti tudományok e terén csak kevés tudományos kutatás született. Az empirikus adatok nagy része a fogyasztói élményparadigma magatartási, társadalmi és pszichológiai aspektusaira vonatkozik (Morgan, 2010).

Gentile et al. (2007) kiemeli a vállalati gyakorlatban még csak kismértékben terjedtek el az élménykoncepciók, amelynek fó okát az elméleti modellek, az egységes terminológia és a menedzsmenteszközök és -módszerek meglétének hiányában látják.

További kutatás indokolt, amely kvalitatív módon képes felmérni, hogy milyen mértékú élményközpontúság jellemzi az egyes szektorok piaci szereplóit. Fényt kell deríteni arra, hogy a fokozott élményközpontúság valóban képes-e versenyelőnyt teremteni, valamint interjúk és megfigyelések módszertanával feltérképezni, hogy milyen élménymenedzsment-módszereket és -eszközöket alkalmaznak az egyes vállalatok. Mindeközben fontos kihangsúlyozni, hogy az élményszemlélet a menedzsment több területén is alkalmazható - az üzletstratégián túl a termékfejlesztésben, a partneri hálózatépítésben vagy a napi szintú operatív folyamatokban.

\section{Lábjegyzet}

${ }^{1}$ A cikk a szerző PhD-disszertációjának témájában készült.

\section{Felhasznált irodalom}

Addis, M. - Holbrook, M.B. (2001): On the conceptual link between mass customization and experiential consumption: An explosion of subjectivity. Journal of Consumer Behaviour, Vol. 1, No. 1: p. 50-66.

Arnould, E. - Price, L. - Zinkhan, G. (2002): Consumers. New York: McGraw-Hill
Berry, L. - Zeithaml, V. - Parasuraman, A. (1985): Quality counts in services too. Business Horizons, Vol. 28: p. 44-52.

Binkhorst, E. - Dekker, T.D. (2009): Agenda for Co-Creation Tourism Experience Research. Journal of Hospitality Marketing \& Management, Vol. 18, No. 2: p. 311-327.

Bitner, M. J. (1992): Servicescapes: the impact of physical surroundings on customers and employees. Journal of Marketing, Vol. 56, No. 2: p. 57-71.

Boswijk, A. - Thijssen, T. - Peelen, E. (2007): The experience economy, a new perspective. Amsterdam: Pearson Education Benelux

Buhalis, D. (2003): eTourism: Information Technology for Strategic Tourism Management. London: FT Prentice Hall

Carlson, R. (1997): Experienced Cognition. New York: Lawrence Erlbaum Association

Caru, A. - Cova, B. (2003): Revisiting consumption experience: A more humble but complete view of the concept. Marketing Theory, Vol. 3, No. 2: p. 267-286.

Caru, A. - Cova, B. (2007): Consumption Experience, London: Routledge

Cova, B. - Dalli, D. (2009): Working consumers: the next step in marketing theory? Marketing Theory, Vol. 9, No. 3: p. 315-339.

Csíkszentmihályi, M. (1990): Flow: The Psychology of Optimal Experience - Steps Toward Enhancing the Quality of Life. New York: HarperCollins Publisher

ETC (2006): Tourism Trends for Europe. European Travel Commission, Brussels, http://www.etc-corporate. org/resources/uploads/ETC_Tourism_Trends_for_ Europe_09-2006_ENG.pdf, (2010. szeptember 18.).

Firat, A.F. - Venkatesh, A. (1995): Liberatory Postmodernism and the Reenchantment of Consumption. Journal of Consumer Research, Vol. 22, No. 3: p. 239-267.

Fisher, D. - Smith, S. (2011): Cocreation is chaotic: What it means for marketing when no one has control. Marketing Theory, Vol. 11, No. 3: p. 325-350.

Gentile, C. - Spiller, N. - Noci, G. (2007): How to Sustain the Customer Experience: An Overview of Experience Components that Co-create Value with the Consumer. European Management Journal, Vol. 25, No. 5: p. 395-410.

Gibbs, D. - Ritchie, C. (2010): Theatre in Restaurants: Constructing the Experience. in: Morgan M. - Lugosi P. - Ritchie, J. R. B. (eds.) (2010): The Tourism and Leisure Experience: Consumer and Managerial Perspectives. Bristol: Channel View Publications: p. 182-201.

Gillespie, C. (2001): European Gastronomy into the $21^{\text {st }}$ Century. Oxford: Elsevier Butterworth Heinemann

Gilmore, H.J. - Pine, II B.J. (2002a): The Experience IS the Marketing. Amazon.com eDoc: Brown Herron Publishing

Gilmore, H.J. - Pine, II B.J. (2002b): Differentiating Hospitality Operations Via Experiences: Why Selling Services is Not Enough. Cornell Hotel and Restaurant Administration Quarterly, 43 (3): p. 87-96. 
Gobe, M. - Gob, M. - Zyman, S. (2001): Emotional branding: the new paradigm for connecting brands to people. New York: Allworth Press

Gronroos, C. (1985): Internal marketing - theory and practice. in: T. Bloch - G. Upah - V. Zeithaml (eds.) (1985): Services Marketing in a Changing Environment. Chicago: American Marketing Association: p. 41-47.

Grove, S.J. - Fisk, R.P. (1989): Impression management in service experience: a managerial approach. in: T.A. Swartz - S. Brown - D. Bowen (eds.) (1989): Advances in Service Marketing and Management. Greenwich CT: JAI Press: p. 427-438.

Grove, S.J. - Fisk, R.P. - Bitner, M.J. (1992): Dramatising the service experience: a managerial approach. in: T.A. Swartz - S. Brown - D. Bowen (eds.) (1992): Advances in Service Marketing and Management. Greenwich CT: JAI Press: p. 91-121.

Hetzel, P. (2002): Planète conso: marketing expérientiel et nouveaux univers de consommation. Paris: Editions d'Organisation

Holbrook, M.B. - Hirschman, E.C. (1982): The experiential aspects of consumption: consumer fantasies, feelings, and fun. Journal of Consumer Research, Vol. 9, September: p. 132-140.

Holbrook, M.B. (2001): Times Square, Disneyphobia, HegeMickey, the Ricky Principle, and the downside of the entertainment economy. Marketing Theory, Vol. 1, No. 2: p. 139-163.

Holt, D.B. (1995): How Consumers Consume - a Typology of Consumption Practices. Journal of Consumer Research, Vol. 22, No. 1: p. 1-16.

Holyfield, L. (1999): Manufacturing adventure: the buying and selling of emotions. Journal of Contemporary Ethnography, Vol. 28, February: p. 3-32.

Hosany, S. - Gilbert, D. (2009): Measuring Tourists's Emotional Experiences toward Hedonic Holiday Destinations. Journal of Travel Research, Vol. 49, No. 4: p. 513-526.

Hultén, B. - Broweus, N. - Van Dijk, M. (2009): Sensory Marketing. New York: Palgrave Macmillan

Kim, Y. K. (2001): Experiential Retailing: an interdisciplinary approach to success in domestic and international retailing. Journal of Retailing and Consumer Services, Vol. 8: p. 287-289.

LaSalle, D. - Britton, T.A. (2003): Priceless: turning ordinary products into extraordinary experiences. Boston: Harvard Business School Press

Lewis, R.C. - Chambers, R.E. (2000): Marketing Leadership in Hospitality. New York: John Wiley

Lugosi, P. (2007): Consumer participation in commercial hospitality. International Journal of Culture, Tourism and Hospitality Research, Vol. 1, No. 3: p. 227-236.

Lusch, R.F. - Vargo, S.L. - O'Brien, M. (2006): Competing through Service: insights from service-dominant logic. Journal of Retailing, Vol. 83, No. 1: p. 5-18.
Mehmetoglu, M. - Engen, M. (2011): Pine and Gilmore's Concept of Experience Economy and Its Dimensions: an empirical examination in tourism. Journal of Quality Assurance in Hospitality and Tourism, Vol. 12: p. 237-255.

Morgan, M. (2010): The Experience Economy 10 Years On: where next for experience management. in: M. MorganP. Lugosi - J. R. B. Ritchie (eds.) (2010): The Tourism and Leisure Experience: consumer and managerial perspectives. Bristol: Channel View Publications: p. 218-230.

Morgan, M. - Elbe, J. - Curiel de Esteban, J. (2009): Has the experience economy arrived?: the views of destination managers in three visitor-dependent areas. International Journal of Tourism Research, Vol. 11: p. 201-216.

Mossberg, L. (2007): A marketing approach to the tourist experience. Scandinavian Journal of Hospitality and Tourism, Vol. 7, No. 1: p. 59-74.

Nijs, D. (2003): Imagineering: engineering for imagination in the emotion economy. in: F. Peeters - F. Schouten - D. Nijs (eds.) (2003): Creating a Fascinating World. Breda: NHTV: p. 15-32.

Petkus, E. (2004): Enhancing the application of experiential marketing in the arts. International Journal of Nonprofit and Voluntary Sector Marketing, Vol. 9, No. 1: p. 49-57.

Pine, B.J. - Gilmore, J.H. (1998): Welcome to the experience economy: work is theatre and every business is a stage. Harvard Business Review, Vol. 76, No. 4: p. 97--105.

Pine, B.J. - Gilmore, J.H. (1999): The Experience Economy: work is theatre \& every business a stage. Boston: Harvard Business School Press

Prahalad, C.K. - Ramaswamy, V. (2000): Co-opting Customer Competence. Harvard Business Review, Vol. 78, January: p. 79-90.

Prahalad, C. K. - Ramaswamy, V. (2003): The New Frontier of Experience Innovation. Sloan Management Review, Vol. 44, Summer: p. 12-18.

Prahalad, C.K. - Ramaswamy, V. (2004a): The Future of Competition: co-creating unique value with customers. Boston: Harvard Business School Press

Prahalad, C.K. - Ramaswamy, V. (2004b): Co-creation Experiences: the next practice in value co-creation. Journal of Interactive Marketing, Vol. 18, No. 3: p. 5-14.

Puczkó, L. (2009): A szabad munkától a munkás szabadságig - és vissza! Magyar Fogyasztó, No. 1: p. 24-26. http:// www.magyarfogyaszto.hu/file/MFSZ_SZI.pdf (2012. február 15.).

Ritzer, G. - Liska, A. (1997): McDisneyization and posttourism: complementary perspectives on contemporary tourism. in: C. Rojek - J. Urry (eds.) (1997): Touring Cultures: transformation of travel and theory. London: Routledge: p. 96-109.

Ritzer, G. - Jurgenson, N. (2010): Production, Consumption, Prosumption: the nature of capitalism in the age of the digital "prosumer". Journal of Consumer Culture, Vol. 10, No. 1: p. 13-36. 
Schmitt, B.H. (1999): Experiential Marketing: how to get customers to sense, feel, think, act and relate to your company and brands. New York: Free Press

Schmitt, B.H. (2003): Customer Experience Management: a revolutionary approach to connecting with your customer. New Jersey: Wiley and Sons

Shaw, C. - Ivens, J. (2005): Building Great Customer Experiences. New York: MacMillan

Sherry, J., Jr-Kozinets, R. - Borghini, S. (2007): Agents in Paradise: experiential co-creation though emplacement, ritualization and community. in: A. Caru - B. Cova (eds.)
(2007): Consumption Experience. Oxon: Routledge: p. 17-33.

Smith, S. - Wheeler, J. (2002): Managing the Customer Experience. London: Prentice Hall

Sundbo, J. (2009): Innovation in the experience economy: a taxonomy of innovation organisations. The Service Industries Journal, Vol. 29, No. 3-4: p. 431-455.

Toffler, A. (1970): Future Shock; New York: Bantam Books Vargo, S.L. - Lusch, R.F. (2004): Evolving to a New Dominant Logic for Marketing. Journal of Marketing, Vol. 68, January: p. 1-17. 